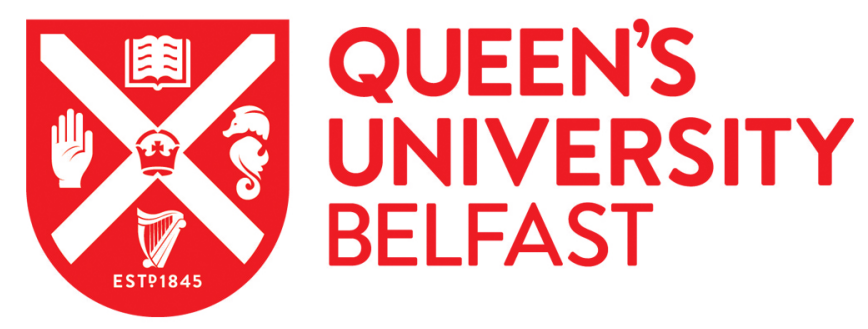

\title{
Nitrogen balance and groundwater nitrate contamination: Comparison among three intensive cropping systems on the North China Plain
}

Ju, X. T., Kou, C. L., Zhang, F. S., \& Christie, P. (2006). Nitrogen balance and groundwater nitrate contamination: Comparison among three intensive cropping systems on the North China Plain. Environmental Pollution, 143(1), 117-125. https://doi.org/10.1016/j.envpol.2005.11.005

Published in:

Environmental Pollution

Queen's University Belfast - Research Portal:

Link to publication record in Queen's University Belfast Research Portal

\section{General rights}

Copyright for the publications made accessible via the Queen's University Belfast Research Portal is retained by the author(s) and / or other copyright owners and it is a condition of accessing these publications that users recognise and abide by the legal requirements associated with these rights.

Take down policy

The Research Portal is Queen's institutional repository that provides access to Queen's research output. Every effort has been made to ensure that content in the Research Portal does not infringe any person's rights, or applicable UK laws. If you discover content in the Research Portal that you believe breaches copyright or violates any law, please contact openaccess@qub.ac.uk. 


\title{
Nitrogen balance and groundwater nitrate contamination: Comparison among three intensive cropping systems on the North China Plain
}

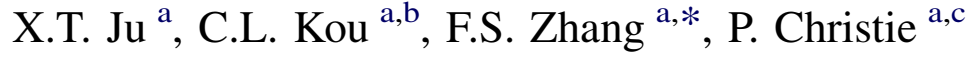 \\ ${ }^{a}$ Key Laboratory of Plant-Soil Interactions, Ministry of Education, College of Agricultural Resources and Environmental Sciences, \\ China Agricultural University, Beijing 100094, China \\ ${ }^{\mathrm{b}}$ Institute of Soils and Fertilizers, Henan Academy of Agricultural Sciences, Zhengzhou 450002, China

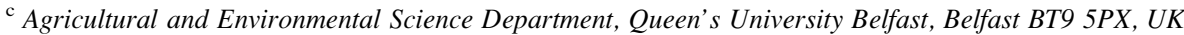

Received 23 August 2005; received in revised form 28 October 2005; accepted 3 November 2005

Intensive greenhouse vegetable production systems may pose a greater nitrogen pollution threat than apple orchards or cereal rotations to soil and water quality in north China.

\begin{abstract}
The annual nitrogen $(\mathrm{N})$ budget and groundwater nitrate-N concentrations were studied in the field in three major intensive cropping systems in Shandong province, north China. In the greenhouse vegetable systems the annual $\mathrm{N}$ inputs from fertilizers, manures and irrigation water were 1358,1881 and $402 \mathrm{~kg} \mathrm{Nha}^{-1}$ on average, representing 2.5, 37.5 and 83.8 times the corresponding values in wheat (Triticum aestivum L.)maize (Zea mays L.) rotations and 2.1, 10.4 and 68.2 times the values in apple (Malus pumila Mill.) orchards. The N surplus values were 349,3327 and $746 \mathrm{~kg} \mathrm{~N} \mathrm{ha}^{-1}$, with residual soil nitrate- $\mathrm{N}$ after harvest amounting to $221-275,1173$ and $613 \mathrm{~kg} \mathrm{~N} \mathrm{ha}^{-1}$ in the top $90 \mathrm{~cm}$ of the soil profile and $213-242,1032$ and $976 \mathrm{~kg} \mathrm{~N}^{-1}$ at $90-180 \mathrm{~cm}$ depth in wheat-maize, greenhouse vegetable and orchard systems, respectively. Nitrate leaching was evident in all three cropping systems and the groundwater in shallow wells $(<15 \mathrm{~m}$ depth) was heavily contaminated in the greenhouse vegetable production area, where total $\mathrm{N}$ inputs were much higher than crop requirements and the excessive fertilizer $\mathrm{N}$ inputs were only about $40 \%$ of total $\mathrm{N}$ inputs.
\end{abstract}

(C) 2005 Elsevier Ltd. All rights reserved.

Keywords: Nitrogen balance; Wheat-maize rotations; Greenhouse vegetables; Apple orchards; Groundwater nitrate contamination; North China Plain

\section{Introduction}

There has been a strongly increasing trend towards the growth of crops of high economic value (including vegetables and fruit trees) in China over the last 20 years. From 1980 to 2002 the area under cereal crops stabilized at about $110 \mathrm{M}$ ha but the area under vegetables increased from 3.16 to $17.35 \mathrm{M}$ ha and under fruit trees from 1.78 to $9.10 \mathrm{M}$ ha (China Agricultural Yearbook, 1981-2003). However, there has

\footnotetext{
* Corresponding author. Tel.: +86 1062732499 ; fax: +86 1062731016 E-mail address: zfs@cau.edu.cn (F.S. Zhang).
}

been poor development of rational fertilizer recommendations in the areas with rapidly expanding production systems, with the result that farmers usually apply large amounts of $\mathrm{N}$ fertilizers and organic manures in order to ensure high yields. A systematic investigation conducted in Shandong province in $1997 / 1998$ found that the average $\mathrm{N}$ fertilizer rate was $280 \mathrm{~kg} \mathrm{~N} \mathrm{ha}^{-1}$ in 957 winter wheat fields, $208 \mathrm{~kg} \mathrm{~N} \mathrm{ha}^{-1}$ in 896 summer maize fields, $1700 \mathrm{~kg} \mathrm{~N} \mathrm{ha}^{-1}$ per crop in 147 protected vegetable fields (plastic film greenhouses), and $848 \mathrm{~kg} \mathrm{~N} \mathrm{ha}^{-1}$ in 217 apple orchards (Ma, 1999). Excessive $\mathrm{N}$ fertilizer application is therefore very common, especially in intensive vegetable and fruit producing areas, and might be expected to lead to nitrate pollution of groundwater. 
In a European study, the nitrate concentration in groundwater samples from $22 \%$ of the agricultural area exceeded the threshold recommended by the World Health Organization (50 $\mathrm{mg} \mathrm{NO}_{3} \mathrm{~L}^{-1}$ ) for drinking water (Laegreid et al., 1999). Legislation has been introduced to enforce the control of $\mathrm{N}$ balance on a farm scale in some European countries to control nitrate pollution of groundwater (Eichler and Schulz, 1998). In a US study conducted in Wisconsin, $\mathrm{NO}_{3}^{-}-\mathrm{N}$ concentrations exceeding $10 \mathrm{mg} \mathrm{N} \mathrm{L}^{-1}$ (the threshold for drinking water set by the US Environmental Protection Agency) were found in $10 \%$ of 800,000 wells, and $17-26 \%$ of wells in the agricultural production areas exceeded the limit (Postle, 1999). Nitrate contamination in groundwater is closely related to the corresponding agricultural management practices (Keeney and Follett, 1991; Rass et al., 1999). Using ${ }^{15} \mathrm{~N}$ tracer techniques, Townsend et al. (1996) found that high nitrate-N concentrations $\left(12-60 \mathrm{mg} \mathrm{N} \mathrm{L}^{-1}\right)$ in groundwater in the southwest of Kansas resulted from high application rates of $\mathrm{N}$ fertilizer to sugar beet fields. Thorburn et al. (2003) investigated groundwater nitrate- $\mathrm{N}$ concentrations in intensive agriculture areas of northeast Australia using ${ }^{15} \mathrm{~N}$ techniques and found that $14-21 \%$ of the wells were contaminated by nitrate, and in about half of these the nitrate was derived from $\mathrm{N}$ fertilizer application. A survey of groundwater nitrate-N concentrations conducted by staff of the Chinese Academy of Agricultural Science in the provinces of Beijing, Tianjin, Hebei, Shandong and Shanxi showed that about $45 \%$ of 600 groundwater samples exceeded the WHO and European limit for nitrate in drinking water of $11.3 \mathrm{mg} \mathrm{NO}_{3}^{-}-\mathrm{N} \mathrm{L}^{-1}\left(50 \mathrm{mg} \mathrm{NO}_{3}^{-} \mathrm{L}^{-1}\right)$, with the highest nitrate- $\mathrm{N}$ concentration reaching $113 \mathrm{mg} \mathrm{L}^{-1}$ (Zhang et al., 2004). The proportion of samples above the limit was much higher in intensive vegetable farming regions than in other cropping areas. However, there have been few systematic studies comparing the impacts of different cropping systems on soil nitrate accumulation and groundwater contamination in China, and there is an urgent need for reliable information on $\mathrm{N}$ losses to the environment in different intensive cropping systems.

High nitrate accumulation and the free flow of water in the soil profile are pre-conditions for nitrate leaching into the subsoil or groundwater. Residual nitrate can move continuously downwards and be lost even if it is not leached during the season of application. Davies and Sylvester-Bradley (1995) found that the annual amount of $\mathrm{NO}_{3}^{-}-\mathrm{N}$ leached in agricultural land in Britain increased by $36 \mathrm{~kg} \mathrm{~N} \mathrm{ha}^{-1}$ over a 50 -year period and one-third was derived from residual nitrate. Another study showed that $68 \%$ of $\mathrm{NO}_{3}^{-}-\mathrm{N}$ accumulation occurred outside the rooting zone and $20 \%$ of $\mathrm{NO}_{3}^{-}-\mathrm{N}$ accumulation in the root zone in the soil profile moved into groundwater annually (Yadav, 1997). In addition to environmental factors such as climate and soil properties, nitrate leaching is also strongly affected by management practices such as fertilizer application, irrigation and planting patterns. Differences in the $\mathrm{N}$ uptake capacity of crops, fertilizer management, and irrigation in different cropping systems may lead to different patterns of nitrate accumulation in the soil profile. In particular, when the $\mathrm{N}$ application rate exceeds crop demand, considerable nitrate accumulation occurs in the soil profile (Granstedt, 2000; Ju et al., 2004). Accumulated nitrate is prone to leaching into the subsoil after high irrigation rates or heavy rainfall (Ju et al., 2003), and thus irrigation agriculture poses a high risk of groundwater nitrate contamination when combined with high fertilizer and water inputs (Diez et al., 2000; Stites and Kraft, 2000). The relationships between soil nitrate accumulation and groundwater nitrate concentrations in different cropping systems are still not fully understood.

Calculation of $\mathrm{N}$ balance is one potentially useful method for predicting the risk of nitrate leaching into groundwater (Barry et al., 1993; Puckett et al., 1999). Many factors influence the degree to which different inputs and outputs can maintain soil fertility while minimizing environmental pollution (Schroder et al., 1996; Parris, 1998). A study by Schleef and Kleihanss (1994) indicated that $100 \mathrm{~kg} \mathrm{ha}^{-1}$ of annual $\mathrm{N}$ surplus could be regarded as a baseline for nitrate leaching into ground- or surface-water on a regional scale. The climate on the North China Plain is warm-temperate subhumid continental monsoon, with cold winters and hot summers. The annual cumulative mean temperature for days with mean temperatures over $10{ }^{\circ} \mathrm{C}$ is $4000-5000{ }^{\circ} \mathrm{C}$ and the annual frost-free period is 175-220 days (Sun et al., 1994). Taking into account the abundance of solar radiation and the high temperatures, shortages of water and nutrients are the main limiting factors for adequate crop yields (Zhu et al., 1994; Sun et al., 1994). The annual precipitation is $500-700 \mathrm{~mm}$, with $60-70 \%$ of the rainfall occurring during summer (June-August). The amount and distribution pattern of rainfall vary widely among years as affected by the continental monsoon climate. Farmers in this region usually irrigate with large amounts of water and apply large amounts of $\mathrm{N}$ fertilizer to obtain high yields (Chen, 2003). These practices lead to a large accumulation of nitrate in the soil profile. The accumulated residual nitrate is readily leached down to deeper soil layers during the summer maize growing season due to heavy rainfall, resulting in the pollution of shallow surface water bodies (Zhang et al., 1996; Liu et al., 2003). The objectives of the present study were therefore to compare the $\mathrm{N}$ balance, soil nitrate accumulation and groundwater nitrate contamination in three typical intensive cropping systems in order to understand the impacts of changes in crop $\mathrm{N}$ management practices on the environment.

\section{Materials and methods}

\subsection{Site description}

Huimin County, Shandong province was selected as the study site because it was considered to be representative of the intensive agricultural areas on the North China Plain. The site is located on the north shore of the lower reaches of the Yellow River in the northeast of Shandong province on the alluvial plain at $37^{\circ} 6^{\prime}-37^{\circ} 36^{\prime} \mathrm{N}, 117^{\circ} 16^{\prime}-117^{\circ} 49^{\prime} \mathrm{E}$. There is an area of flat agricultural land of 73,480 ha with a mean altitude of $12.8 \mathrm{~m}$ and a gradient of 1:6000 at ground surface. The average temperature is $12.3{ }^{\circ} \mathrm{C}$ with 182 frost-free days each year. Annual average precipitation is $578 \mathrm{~mm}$ (over a recent 30-year period), of which $61-84 \%$ occurs between June and August. The annual 
average evaporation is $1882 \mathrm{~mm}$ and is typical of the warm-temperate subhumid continental monsoon climate. The precipitation in the year of study from October 2002 to September 2003 was $508 \mathrm{~mm}$, and $304 \mathrm{~mm}$ in June, July and August, accounting for $60 \%$ of total rainfall during the year. The main soil type is loamy silty alluvial soil (FAO system). The contents of sand, silt and clay are $51-64,21-36$ and $9-21 \%$, respectively. The main crops grown are wheat, maize, greenhouse vegetables, cotton (Gossypium hirsutum Linn.) and fruit trees, of which the wheat-maize rotation system accounts for $66 \%$, vegetables for $19 \%$ and fruit trees for $11 \%$ of the total cultivated area.

\subsection{Methods of sampling}

\subsubsection{Selection of sampling sites}

A multistage sampling technique was used to select representative fields for sampling plants and soils from each cropping system as follows. Firstly, we randomly selected five typical townships that had all three cropping systems from a total of 14 townships throughout the county. Secondly, we randomly selected two villages from a total of 63-103 villages in each selected township. Finally, a number of fields were randomly selected in each selected village for sampling of crops and soils from each of the three cropping systems.

\subsubsection{Plant sampling}

Plant sampling of wheat and maize was conducted at harvest time in 47 commercial fields belonging to 10 villages. Wheat was harvested from five separate randomly selected $1-\mathrm{m}^{2}$ sites in each field and separated into grain, straw and chaff, and then weighed after oven-drying to calculate the grain and straw yields. Plant samples were also taken to analyze the $\mathrm{N}$ content of different plant parts to calculate total plant $\mathrm{N}$ uptake. For maize, planting density was investigated in four rows at 4-m lengths in five random sites in each field. Five plants were harvested from the five random sites in each field and separated into grain, straw and cobs, and then the grain and straw yields and total plant $\mathrm{N}$ uptake were determined as for wheat. Fifty-six greenhouses (36 of cucumber (Cucumis sativus Linn.), 9 of tomato (Lycopersicon esculentum Mill.) and 11 of capsicum pepper (Capsicum anпиит Linn.)) were selected in the same 10 villages. The land had been used to grow wheat - maize rotations before the plastic film greenhouses were established 3-20 years previously. Fruit samples were collected from 10 plants in each greenhouse at each harvest. The aboveground vines and leaves of the plants were also collected after the final harvest and all plant samples were oven-dried, weighed and analyzed for $\mathrm{N}$ to calculate total biomass and total plant $\mathrm{N}$ uptake. Thirtyfour apple orchards, which had been in use for 5-13 years, were selected to investigate $\mathrm{N}$ inputs and outputs in above 10 villages. The $\mathrm{N}$ removed by fruits was calculated on the basis of $4 \mathrm{~kg} \mathrm{~N} \mathrm{ha}^{-1}$ in $1000 \mathrm{~kg} \mathrm{ha}^{-1}$ fruit (Liu et al., 2002).

\subsubsection{Soil sampling}

Soil samples were taken from all the experimental fields after the harvest of each crop. The sampling time of wheat was from 11 to 24 June 2003, of maize from 29 September to 6 October 2003, of cucumber and tomato from 1 to 15 July 2003, of capsicum from 13 to 26 August and of apples from 18 to 27 October 2003. Samples were collected from five sites in each field of wheat, maize, vegetables and apple trees at $30-\mathrm{cm}$ intervals from the top $180 \mathrm{~cm}$ of the soil profile. Soil samples from all five sites in same field were mixed thoroughly to obtain composite samples from each depth layer, placed in labeled plastic bags, sealed and stored in ice boxes before analysis for $\mathrm{NH}_{4}^{+}-\mathrm{N}$ and $\mathrm{NO}_{3}^{-}-\mathrm{N}$ in the laboratory.

\subsubsection{Sampling of groundwater and irrigation water}

Fifty-three wells were selected across the growing areas of the three cropping systems to monitor changes in groundwater nitrate dynamics over 1 year. There were 18 wells distributed in the wheat-maize fields, 18 in the greenhouse areas and 17 in the apple orchard areas. The wells were selected using three criteria. Firstly, each well had to be located within one of the planted areas in order to reflect the long-term effects of aboveground agricultural management on groundwater nitrate concentrations within the cropping system. Secondly, wells of different depths in the same cropping system were selected to collect groundwater samples from different depths. Thirdly, the wells were located in the same fields where plant and soil samples were collected. Groundwater samples were collected once a month from every well and the depth of the groundwater table was also measured. The samples were placed in 150-mL polyethylene bottles, sealed and frozen prior to analysis for $\mathrm{NH}_{4}^{+}-\mathrm{N}$ and $\mathrm{NO}_{3}^{-}-\mathrm{N}$.

During periods of irrigation of wheat, maize, vegetables and apple trees, irrigation water samples were collected and the amount of irrigation water was recorded for each field. The water used to irrigate wheat, maize and apple trees was derived mainly from channel systems connected to pumping systems of the Yellow River. The irrigation water for vegetables was mainly from shallow groundwater pumped from an adjacent greenhouse. Water samples were placed in $150-\mathrm{mL}$ polyethylene bottles, sealed and frozen before analysis for $\mathrm{NH}_{4}^{+}-\mathrm{N}$ and $\mathrm{NO}_{3}^{-}-\mathrm{N}$.

\subsubsection{Rainwater sampling}

Rainwater samples were collected from three sites in Huimin County during each rainfall event over 1 year using rain gauges. The samples were stored frozen in $150-\mathrm{mL}$ polyethylene bottles prior to analysis for $\mathrm{NH}_{4}^{+}-\mathrm{N}$ and $\mathrm{NO}_{3}^{-}-\mathrm{N}$.

\subsubsection{Sampling of farmyard manure}

The main types of organic manure used by local farmers are cattle, pig and chicken manures, and hemp seed cake, bean cake and cottonseed cake. Samples of these manures were collected when farmers were applying them in the field. Samples of about $1 \mathrm{~kg}$ were collected from 10 to 15 points within each manure heap. They were placed on clean plastic boards, broken up and mixed thoroughly and a sub-sample of about $0.5 \mathrm{~kg}$ was obtained using the quartering procedure. Part of this sub-sample was used to determine water content and the remainder was air-dried for nutrient analysis. Three to seven samples of each type of manure were obtained. Wheat and maize straw were regarded as part of the organic $\mathrm{N}$ returned to the field. The amount of straw returned to the field was determined at harvest time.

\subsection{Sample analysis}

Each fresh soil sample was extracted with $0.01 \mathrm{~mol} \mathrm{~L}^{-1} \mathrm{CaCl}_{2}$ to determine the concentrations of $\mathrm{NH}_{4}^{+}-\mathrm{N}$ and $\mathrm{NO}_{3}^{-}-\mathrm{N}$ using a Continuous Flow Analyzer (TRAACS 2000, Bran and Luebbe, Norderstedt, Germany). 'Total' $\mathrm{N}$ in plant and manure samples was analyzed by the Kjeldahl method. The concentrations of $\mathrm{NH}_{4}^{+}-\mathrm{N}$ and $\mathrm{NO}_{3}^{-}-\mathrm{N}$ in groundwater, irrigation water and rainwater were analyzed using the Continuous Flow Analyzer.

\subsection{Method of calculation of nitrogen balance}

\subsubsection{Basic database of experimental fields}

The basic data were investigated by recording management practices in every selected field over 1 year from 2002 to 2003, including the area of the field, the age of the greenhouse or fruit trees, the types and amount of fertilizer applied, and the seed rate and crop variety. Evidence from farmer interviews was used to ensure that the management history of each field was similar to the practices followed during the year of the investigation.

\subsubsection{Calculation of nitrogen balance}

Soil nitrogen balance was calculated by following formula (van Eerdt and Fong, 1998; Oenema et al., 2003):

$$
\begin{aligned}
\text { Nitrogen surplus }= & \text { input components }(\text { fertilizer }+ \text { manure } \\
& + \text { nitrogen from seed }+ \text { wet deposition } \\
& + \text { nitrogen from irrigation })- \text { output components } \\
& \text { (N removed by aboveground plant parts }) .
\end{aligned}
$$

The surplus $\mathrm{N}$ represented $\mathrm{N}$ that was lost by ammonia volatilization, denitrification or leaching, or stored in various soil fractions. 


\subsubsection{Calculation of input and output components}

$\mathrm{N}$ inputs from fertilizers were calculated from the amount of fertilizers applied, and the forms and concentrations of nutrients present. The main fertilizers used in the study fields were urea, ammonium bicarbonate, diammonium phosphate, compound or mixed fertilizers. $\mathrm{N}$ inputs from organic manures were also estimated.

$\mathrm{N}$ inputs from wheat and maize seeds were calculated from the sowing rate and seed $\mathrm{N}$ concentrations. $\mathrm{N}$ inputs from vegetable and apple seeds were considered to be negligible because of the very low sowing rate in the greenhouses and the apple trees were transplanted into the orchards as small seedlings.

$\mathrm{N}$ inputs from irrigation water were calculated from the amount of irrigation water used and the $\mathrm{N}$ concentrations in water samples summed over the year. In wheat-maize rotations and apple orchards the wet deposition inputs were estimated from October 2002 to September 2003, and in the greenhouses from 15 June 2003 to 15 September 2003 because they were covered by plastic film at other times.

$\mathrm{N}$ outputs in aboveground plant parts were calculated from the $\mathrm{N}$ concentration in each harvested component of the plant samples and the oven-dry yield, and added up for each field.

\subsection{Statistical analysis}

The primary data were manipulated using Microsoft Excel spreadsheets. The significance of fertilizers, $\mathrm{N}$ balance, and soil nitrate accumulation among different cropping systems was tested by analysis of variance and mean values were compared by least significant difference (LSD) at the 5\% level using the SAS software package (Version 6.12, 1997; SAS Institute, Inc., Cary, NC, USA).

\section{Results}

\subsection{Nitrogen fertilizer and manure use in the three cropping systems}

The annual $\mathrm{N}$ applied in fertilizers and organic manures and the total $\mathrm{N}$ inputs in the greenhouse vegetable systems were all significantly higher than those in the other two cropping systems. Moreover, $\mathrm{N}$ inputs from fertilizers in the greenhouse systems were $1358 \mathrm{~kg} \mathrm{~N} \mathrm{ha}^{-1}$ on average, or 2.5 times the corresponding values in the wheat-maize rotations and 2.1 times those in the apple orchards (Table 1). $\mathrm{N}$ inputs from manures in the greenhouse vegetable systems were $1881 \mathrm{~kg} \mathrm{~N}^{-1}$ on average, or 37.5 times the corresponding values for wheatmaize rotations and 10.4 times the values for the orchards. Although the annual $\mathrm{N}$ applied in fertilizers and manures and total $\mathrm{N}$ inputs to apple orchards were higher than those in the wheat-maize rotations the apparent differences were not statistically significant.

Table 1

Nitrogen inputs from fertilizer and manure in the three cropping systems $\left(\mathrm{kg} \mathrm{Nha}^{-1} \mathrm{yr}^{-1}\right)$

\begin{tabular}{llcrc}
\hline Cropping system & No. of fields & Fertilizer & Manure & Fertilizer + manure \\
\hline Wheat-maize & 47 & $553 \mathrm{~b}^{\mathrm{a}}$ & $50 \mathrm{~b}$ & $603.2 \mathrm{~b}$ \\
Greenhouse vegetables & 56 & $1358 \mathrm{a}$ & $1881 \mathrm{a}$ & $3239.2 \mathrm{a}$ \\
Apple orchards & 34 & $661 \mathrm{~b}$ & $181 \mathrm{~b}$ & $841.9 \mathrm{~b}$ \\
$F$ value & & 49 & 67 & 126.4 \\
\hline
\end{tabular}

${ }^{\text {a }}$ Within each column, mean values with the same letters are not significant different by LSD at the $5 \%$ level.

\subsection{Nitrogen balance in the three cropping systems}

Annual total $\mathrm{N}$ inputs in the greenhouses ranged from 951 to $8421 \mathrm{~kg} \mathrm{Nha}^{-1}$ and were far higher than in the wheatmaize rotations $\left(226-1002 \mathrm{~kg} \mathrm{Nha}^{-1}\right)$ and apple orchards (159-1507 $\mathrm{kg} \mathrm{Nha}^{-1}$ ), with the last two systems showing no significant differences in annual total $\mathrm{N}$ inputs (Table 2). The $\mathrm{N}$ inputs within each cropping system were very variable among individual fields, reflecting the lack of a rational fertilizer recommendation system. $\mathrm{N}$ inputs from irrigation water in the greenhouse vegetable systems ranged from 4 to $905 \mathrm{~kg} \mathrm{Nha}^{-1}$, and only $0.4-11.3 \mathrm{~kg} \mathrm{~N}$ and $2.0-$ $18.1 \mathrm{~kg} \mathrm{Nha}^{-1}$, respectively, in the wheat-maize rotations and apple orchards. $\mathrm{N}$ from irrigation water in certain older greenhouses was particularly high after the accumulation of $\mathrm{N}$ in the wells over a period of more than 20 years.

Fertilizers were the main source of $\mathrm{N}$ in the wheat-maize rotations, accounting for $88 \%$ of total $\mathrm{N}$ inputs annually, with manures accounting for only $8 \%$, wet deposition $3 \%$, and irrigation water less than $1 \%$. Similarly, fertilizers were the main source of $\mathrm{N}$ in apple orchards, accounting for $76 \%$ of total $\mathrm{N}$ inputs annually, while manure was also an important source of $\mathrm{N}$, supplying $21 \%$ of annual $\mathrm{N}$ inputs, with contributions of $2 \%$ from wet deposition and less than $1 \%$ from irrigation water. In contrast to these two cropping systems, manure was largest source of $\mathrm{N}$ in greenhouse vegetable systems, accounting for $51 \%$ total annual $\mathrm{N}$ inputs and with fertilizers supplying $37 \%$. Interestingly, irrigation water accounted for $11 \%$ of total $\mathrm{N}$ inputs in the greenhouses, presumably largely due to the pumping of shallow groundwater high in $\mathrm{NO}_{3}^{-}-\mathrm{N}$ for irrigation of vegetables.

There were significant differences among the three cropping systems in annual $\mathrm{N}$ outputs (Table 2), with greenhouse vegetable systems $\left(125-630 \mathrm{~kg} \mathrm{~N} \mathrm{ha}^{-1}\right)$ showing significantly higher

Table 2

Annual nitrogen balance in the three cropping systems $\left(\mathrm{kg} \mathrm{ha}^{-1} \mathrm{yr}^{-1}\right)$

\begin{tabular}{|c|c|c|c|}
\hline Cropping system & $\begin{array}{l}\text { Wheat-maize } \\
(n=47)\end{array}$ & $\begin{array}{l}\text { Greenhouse } \\
\text { vegetables }(n=56)\end{array}$ & $\begin{array}{l}\text { Apple } \\
\text { orchards }(n=34)\end{array}$ \\
\hline \multicolumn{4}{|l|}{ Inputs } \\
\hline $\begin{array}{c}\text { Chemical N } \\
\text { fertilizer }\end{array}$ & $553 b^{a}$ & $1358 \mathrm{a}$ & $661 b$ \\
\hline Manure N & $50 \mathrm{~b}$ & $1881 \mathrm{a}$ & $181 b$ \\
\hline $\begin{array}{l}\text { Irrigation } \\
\text { water } \mathrm{N}\end{array}$ & $4.8 \mathrm{~b}$ & $402 a$ & $5.9 b$ \\
\hline Seed N & 6.6 & $\mathrm{ND}^{\mathrm{b}}$ & $\mathrm{ND}^{\mathrm{c}}$ \\
\hline $\begin{array}{l}\text { Wet } \\
\text { deposition } \mathrm{N}\end{array}$ & 18.9 & 14.2 & 18.9 \\
\hline Total input & $629 b$ & $3656 a$ & $867 \mathrm{~b}$ \\
\hline \multicolumn{4}{|l|}{ Outputs } \\
\hline Plant remove & $280 \mathrm{~b}$ & $329 a$ & $121 \mathrm{c}$ \\
\hline \multicolumn{4}{|l|}{$\mathrm{N}$ balance } \\
\hline N surplus & $349 b$ & $3327 \mathrm{a}$ & $746 b$ \\
\hline
\end{tabular}

${ }^{a}$ Within each row, mean values with the same letter are not significant different by LSD at the $5 \%$ level.

${ }^{\mathrm{b}} \mathrm{ND}$, not determined: the negligible $\mathrm{N}$ input from seed in the greenhouse vegetable systems has been ignored.

c ND, not determined: perennial apple trees with no seed $\mathrm{N}$ input. 
values than wheat-maize rotations $\left(206-396 \mathrm{~kg} \mathrm{~N} \mathrm{ha}^{-1}\right)$ or apple orchards $\left(18-210 \mathrm{~kg} \mathrm{~N} \mathrm{ha}^{-1}\right)$. The calculated $\mathrm{N}$ surplus values in vegetable greenhouses $\left(620-8084 \mathrm{~kg} \mathrm{~N} \mathrm{ha}^{-1}\right)$ were much higher than in the cereal rotations ( -66 to $688 \mathrm{~kg} \mathrm{~N} \mathrm{ha}^{-1}$ ) or the apple orchards $\left(69-1365 \mathrm{~kg} \mathrm{Nha}^{-1}\right)$. This surplus $\mathrm{N}$ would have been lost by ammonia volatilization, denitrification or leaching, or stored in various soil fractions.

Annual $\mathrm{N}$ surpluses in wheat-maize rotations and apple orchards were significantly and positively correlated with $\mathrm{N}$ fertilizer application rate (Fig. 1a, b). The annual $\mathrm{N}$ surplus in greenhouse vegetables was not significantly correlated with $\mathrm{N}$ fertilizer application rate, but was significantly and positively correlated with manure application rate (Fig. 1c). This reflects the high inputs of manure $\mathrm{N}$ and the high losses of fertilizer $\mathrm{N}$ in greenhouse vegetable systems (Zhu et al., 2005). Nevertheless, the high intercept $\left(1560 \mathrm{~kg} \mathrm{Nha}^{-1}\right)$ of the regression line between $\mathrm{N}$ surplus and manure $\mathrm{N}$ inputs in the vegetable systems shows that other $\mathrm{N}$ sources also made large contributions to the $\mathrm{N}$ surplus, especially $\mathrm{N}$ fertilizer. If we consider the relationship between $\mathrm{N}$ surplus and both manure and chemical $\mathrm{N}$ inputs, the line was close to passing through the origin, indicating that these two sources comprised the main $\mathrm{N}$ inputs in the greenhouse vegetable systems (Fig. 1d).

\subsection{Accumulation of soil nitrate in the three cropping systems}

Nitrate accumulation in the soil profile showed high variance among individual fields in each cropping system. Nitrate accumulation in the $0-90 \mathrm{~cm}$ soil layer was $270-$ $5038 \mathrm{~kg} \mathrm{~N} \mathrm{ha}^{-1}$ in vegetable greenhouses, $52-609 \mathrm{~kg} \mathrm{~N} \mathrm{ha}^{-1}$ in wheat fields, $120-844 \mathrm{~kg} \mathrm{~N} \mathrm{ha}^{-1}$ in maize fields, and 32$2406 \mathrm{~kg} \mathrm{~N} \mathrm{ha}^{-1}$ in apple orchards. The corresponding ranges of values in the $90-180 \mathrm{~cm}$ soil layer were $224-3273$, $68-1047,28-946$, and $228-2430 \mathrm{~kg} \mathrm{Nha}^{-1}$. The amounts
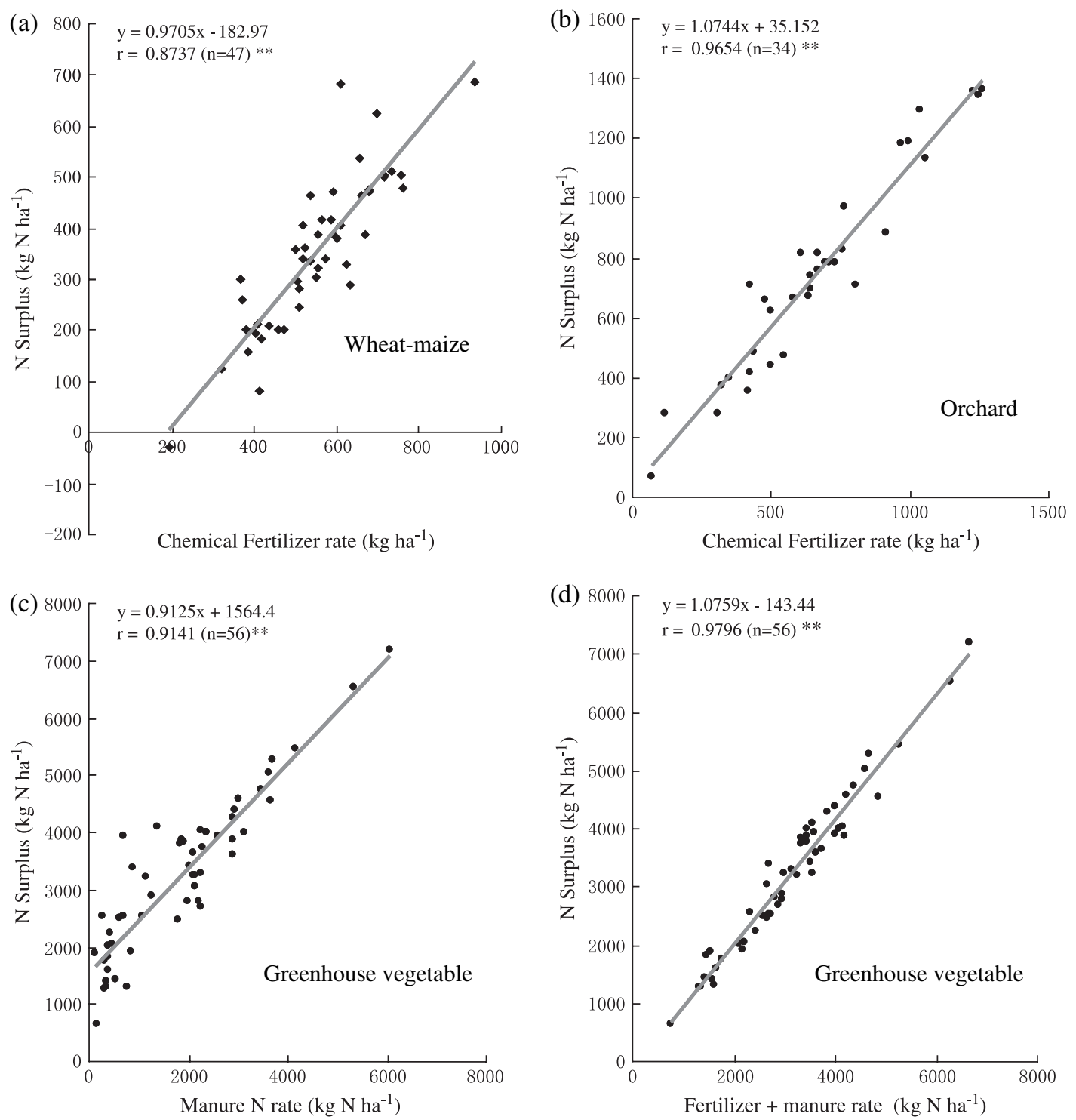

Fig. 1. Correlation between nitrogen surplus and fertilizer $\mathrm{N}$ input in the three cropping systems. 
of nitrate in the $0-90$ and $90-180 \mathrm{~cm}$ soil layers in the greenhouses were significantly higher than in the other two cropping systems (except for the $90-180 \mathrm{~cm}$ soil layers in the greenhouses and apple orchards) (Fig. 2). Large amounts of nitrate accumulated in the $90-180 \mathrm{~cm}$ soil layer indicating substantial leaching of nitrate in the vegetable greenhouses.

The accumulated nitrate- $\mathrm{N}$ was evenly distributed in the $0-180 \mathrm{~cm}$ depth of the soil profile in wheat-maize rotations and greenhouses (except for the $0-30 \mathrm{~cm}$ soil layer), and the average amount accumulated in the $0-90 \mathrm{~cm}$ soil layer was $51 \%$ of total accumulation in the top $180 \mathrm{~cm}$ in wheatmaize fields and $53 \%$ in the greenhouses (Fig. 3). The distribution of nitrate- $\mathrm{N}$ accumulation in the soil profile in apple orchards showed a different trend with more than $60 \%$ in the $90-180 \mathrm{~cm}$ soil layer, significantly higher than the value for the $0-30 \mathrm{~cm}$ soil layer, most likely due to the deep placement of fertilizers in this system (Liu et al., 2002).

\subsection{Nitrate contamination in groundwater in three cropping systems}

In this study the sampling wells were classed as shallow or deep using a depth of $15 \mathrm{~m}$ as the criterion (Baker et al., 1989). Nitrate- $\mathrm{N}$ concentrations in deep wells in wheat-maize rotations were $0-11.8 \mathrm{mg} \mathrm{N} \mathrm{L}^{-1}$ (Table 3), with only two samples exceeding $10 \mathrm{mg} \mathrm{N} \mathrm{L}^{-1}$, and $1 \%$ of the samples exceeded the standard. No samples in deep wells in the apple orchards exceeded $10 \mathrm{mg} \mathrm{N} \mathrm{L}^{-1}$, but $5 \%$ exceeded the standard in the shallow groundwater. Although the average nitrate- $\mathrm{N}$ concentration in deep wells in the greenhouse vegetable systems was only $1.9 \mathrm{mg} \mathrm{N} \mathrm{L}^{-1}$, the proportion exceeding the standard was $5 \%$, a higher frequency of contamination than in the deep wells in the other two cropping systems. Nitrate-N concentrations in shallow wells in the greenhouse vegetable systems ranged from 9 to $274 \mathrm{mg} \mathrm{N} \mathrm{L}^{-1}$, with $99 \%$ exceeding $10 \mathrm{mg} \mathrm{N} \mathrm{L}^{-1}$, more than half of the samples $(53 \%)$ exceeding $50 \mathrm{mg} \mathrm{N} \mathrm{L}^{-1}$, and $26 \%$ exceeding $100 \mathrm{mg} \mathrm{N} \mathrm{L}^{-1}$, indicating

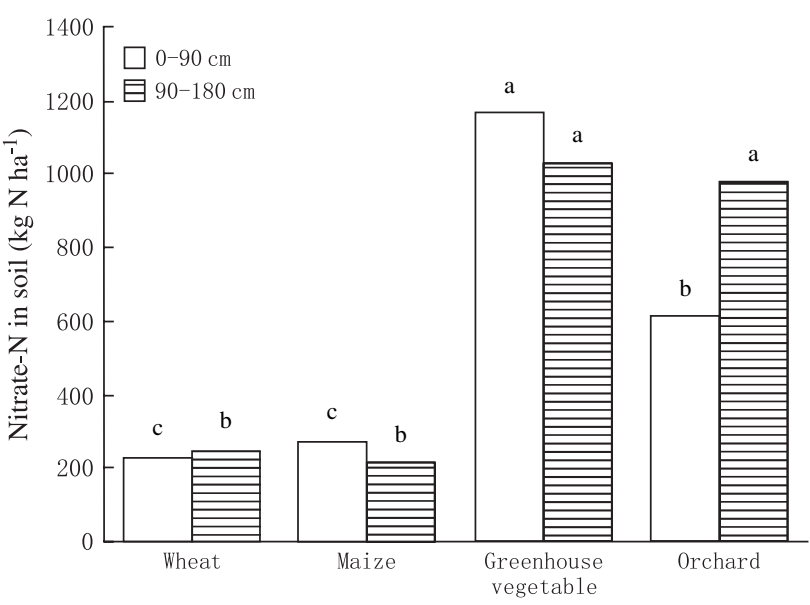

Fig. 2. Nitrate accumulation at $0-180 \mathrm{~cm}$ depth in the soil profile in the three cropping systems. Mean values with the same letters above the bar are not significant different by LSD at the $5 \%$ level within same soil layer.

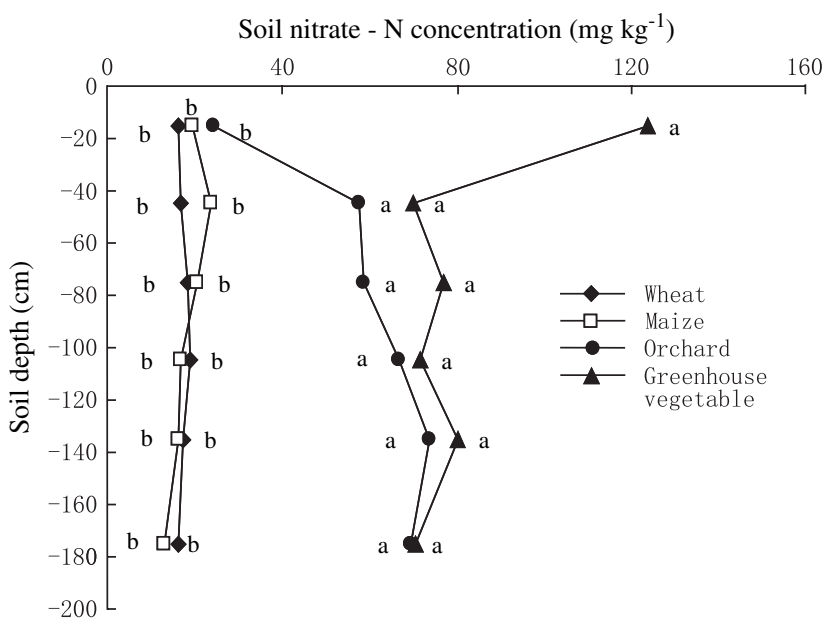

Fig. 3. Distribution of nitrate-N at $0-180 \mathrm{~cm}$ depth in the soil profile in the three cropping systems. Mean values with the same letters beside the point are not significant different by LSD at the 5\% level within same soil layer.

that the shallow groundwater had been severely polluted by nitrate in this cropping system.

The average nitrate- $\mathrm{N}$ concentration of groundwater over a 12-month period decreased exponentially with well depth in the vegetable greenhouses, with the determination coefficient reaching 0.71 . Clearly, shallow groundwater was particularly vulnerable to $\mathrm{NO}_{3}^{-}-\mathrm{N}$ pollution in the greenhouse systems (Fig. 4).

\section{Discussion}

The annual fertilizer $\mathrm{N}$ inputs in all three intensive cropping systems $\left(553,1358\right.$ and $661 \mathrm{~kg} \mathrm{Nha}^{-1}$ in wheat-maize, greenhouse vegetables and apple orchards on average) were higher than the $\mathrm{N}$ fertilizer application rates recommended by the local extension service $(300-390,900$ and $450 \mathrm{~kg} \mathrm{~N} \mathrm{ha}^{-1}$ ). In addition, $1881 \mathrm{~kg} \mathrm{ha}^{-1}$ of manure $\mathrm{N}$ was applied to the vegetable greenhouse soils. Crop yields in these three cropping systems did not increase significantly with increasing $\mathrm{N}$ application rate and there were no significant correlations between yield and $\mathrm{N}$ application rate according to our data analysis. The $\mathrm{N}$ surpluses were significantly correlated with $\mathrm{N}$ application rates. Over-fertilization is common in the study area and is representative of the North China Plain (Chen, 2003; Ju et al., 2004). Weaknesses of the extension services may be partly responsible for these problems, and this is a complex institutional and economic issue (Sonntag et al., 2005). Another key factor behind $\mathrm{N}$ overuse is that the majority of farmers do not take account of $\mathrm{N}$ inputs from manure and irrigation water when they decide how much fertilizer $\mathrm{N}$ to apply, and extension workers do not recommend that they should make such adjustments.

Soil and climatic conditions on the North China Plain are favorable for the processes of mineralization and nitrification (Richter and Roelcke, 2000; Liu et al., 2003; Ju et al., 2004). These conditions, combined with the large $\mathrm{N}$ surpluses, lead to high nitrate accumulation and leaching losses, especially in greenhouses producing vegetables. Although showing 
Table 3

Nitrate-N concentrations in groundwater of the three cropping systems

\begin{tabular}{|c|c|c|c|c|c|c|}
\hline Cropping system & Well depth category (m) & No. of wells & No. of samples & Nitrate-N $\left(\mathrm{mg} \mathrm{L}^{-1}\right)$ & Range $\left(\mathrm{mg} \mathrm{L}^{-1}\right)$ & Nitrate-N $>10 \mathrm{mg} \mathrm{L}^{-1}(\%)$ \\
\hline Wheat-maize & $>15$ & 20 & 220 & 1.0 & $0-11.8$ & 1 \\
\hline Greenhouse vegetables & $\begin{array}{l}<15 \\
>15\end{array}$ & $\begin{array}{r}12 \\
6\end{array}$ & $\begin{array}{r}129 \\
66\end{array}$ & $\begin{array}{r}69.6 \\
1.9\end{array}$ & $\begin{array}{c}8.9-274.4 \\
0-15.3\end{array}$ & $\begin{array}{r}99 \\
5\end{array}$ \\
\hline Apple orchards & $\begin{array}{l}<15 \\
>15\end{array}$ & $\begin{array}{r}14 \\
2\end{array}$ & $\begin{array}{r}163 \\
24\end{array}$ & $\begin{array}{l}1.6 \\
0.4\end{array}$ & $\begin{array}{l}0-20.0 \\
0-2.5\end{array}$ & $\begin{array}{l}5 \\
0\end{array}$ \\
\hline
\end{tabular}

lower accumulation in wheat-maize fields, nitrate in the $0-$ $90 \mathrm{~cm}$ soil layer accumulated to more than $200 \mathrm{~kg} \mathrm{~N} \mathrm{ha}^{-1}$, which was much higher than the $90-100 \mathrm{~kg} \mathrm{~N} \mathrm{ha}^{-1}$ of residual $\mathrm{NO}_{3}^{-}-\mathrm{N}$ in the $0-100 \mathrm{~cm}$ soil layer accepted in Europe as an environmental safety standard after crop harvest (Hofman, 1999). Numerous studies have shown that yields do not increase significantly when $\mathrm{N}$ fertilizer application rate exceeds a certain value, but residual nitrate increases sharply (Raun and Johnson, 1995; Porter et al., 1996; Bhogal et al., 2000; Zhong, 2004). In our study area the groundwater table is usually at a depth range of only $1-3 \mathrm{~m}$, therefore nitrate which has migrated to the subsoil is liable to move into the shallow groundwater. Groundwater nitrate-N concentrations showed large differences among the three cropping systems, but exceeded the standard in all systems, especially in the shallow groundwater $(<15 \mathrm{~m})$ in the vegetable greenhouses, with a highest nitrate-N concentration of $270 \mathrm{mg} \mathrm{L}^{-1}$. High rates of nitrate contamination in vegetable fields have also been reported in other areas of North China (Zhang et al., 1996; Liu et al., 2001, 2005b).

Irrigation agriculture is usually likely to promote groundwater nitrate pollution (Pionke et al, 1990; Guimera, 1998) due to high $\mathrm{N}$ fertilizer and water inputs, the very conditions characteristic of vegetable production. Vegetable crops have shallow root systems and are sensitive to water and nutrient supply, therefore farmers readily apply large amounts of fertilizer and frequently irrigate the fields, leading to leaching of

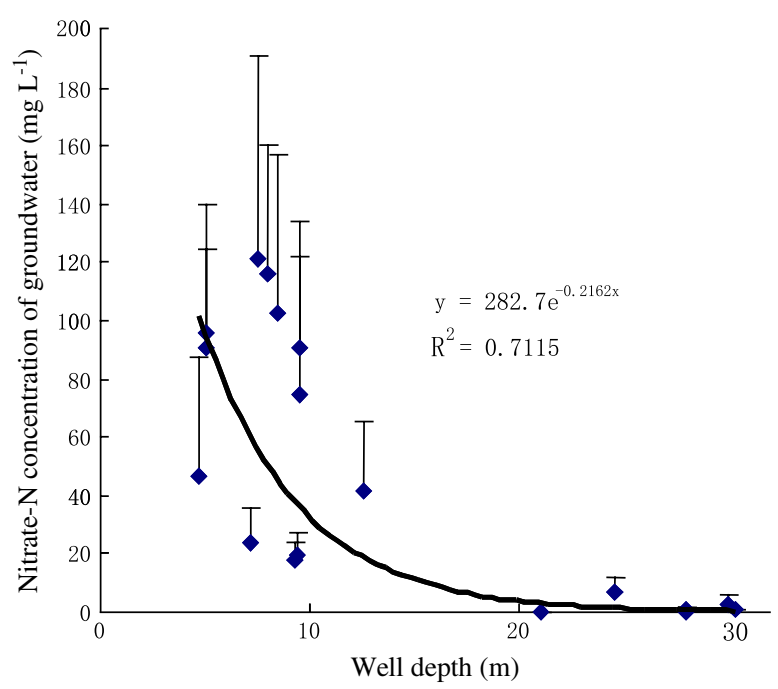

Fig. 4. Correlation between nitrate-N concentration and well depth in the greenhouse vegetable production system.
$\mathrm{NO}_{3}^{-}-\mathrm{N}$ out of the root zone and into the subsoil or shallow groundwater. Some studies have shown amounts of $\mathrm{N}$ leached into groundwater in vegetable fields over $200 \mathrm{~kg} \mathrm{Nha}^{-1}$ (Prunty and Greenland, 1997; Stites and Kraft, 2001; Ramos et al., 2002; Kraft and Stites, 2003), and even over $500 \mathrm{~kg} \mathrm{~N} \mathrm{ha}^{-1}$ in some cases (Pionke et al., 1990; Zhu et al., 2005).

In addition, greenhouses are irrigated with shallow groundwater from the local area, and this supplies large amounts of nitrate- $\mathrm{N}$ due to the high nitrate- $\mathrm{N}$ concentrations in the groundwater. In our study, irrigation water supplied 4$905 \mathrm{~kg} \mathrm{~N} \mathrm{ha}^{-1}$ to greenhouse vegetable soils annually, 107$905 \mathrm{~kg} \mathrm{Nha}^{-1}$ with shallow wells and $4-23 \mathrm{~kg} \mathrm{Nha}^{-1}$ with a few deep wells. These wells with high nitrate-N concentrations have been distributed within intensive greenhouse vegetable areas for more than 20 years, and groundwater $\mathrm{NO}_{3}^{-}-\mathrm{N}$ concentrations can reach $40 \mathrm{mg} \mathrm{L}^{-1}$ annually, especially in areas with greenhouse cucumber production. Guimera (1998) showed similar results in open vegetable fields, with $850 \mathrm{~kg} \mathrm{~N} \mathrm{ha}^{-1}$ supplied by irrigated groundwater and application of $2780 \mathrm{~kg} \mathrm{~N} \mathrm{ha}^{-1}$ from manure and $\mathrm{N}$ fertilizer sources.

Nitrate-N concentrations in deep wells seldom exceeded the maximum standard in wheat-maize rotation areas. Unfortunately, we do not know the situation for shallow groundwater because we did not find any shallow wells in this cropping system. Nevertheless, shallow groundwater has a high risk of being polluted because annual $\mathrm{N}$ fertilizer inputs have reached $553 \mathrm{~kg} \mathrm{~N} \mathrm{ha}^{-1}$ and annual $\mathrm{N}$ surpluses were $354 \mathrm{~kg} \mathrm{~N}$ ha $^{-1}$ on average. In fact, the nitrate- $\mathrm{N}$ concentration in water leaching from a depth of $1.4 \mathrm{~m}$ in the soil profile reached 12$39 \mathrm{mg} \mathrm{L}^{-1}$ after the maize harvest in our study. This risk of groundwater pollution may be stimulated by local agricultural management practices which feature high $\mathrm{N}$ fertilizer inputs combined with flooding irrigation (usually 100-130 mm at each irrigation event).

Although the excess $\mathrm{N}$ inputs in vegetable production are higher on a per unit area basis than in cereal production, we cannot conclude that there is no diffuse $\mathrm{N}$ pollution in cereal production. Annual surpluses of $>300 \mathrm{~kg} \mathrm{~N} \mathrm{ha}^{-1}$ are likely to occur every year in a double wheat-maize rotation (on $66 \%$ of the total cultivated area) and are likely to lead to excessive $\mathrm{N}$ accumulation. These inputs and the surpluses of $>3000 \mathrm{~kg} \mathrm{Nha}^{-1} \mathrm{yr}^{-1}$ in the vegetable production systems (on $19 \%$ of the land area) indicate that both production systems will be important sources of $\mathrm{N}$ pollution.

The proportion of shallow groundwater wells exceeding the standard was $5 \%$ in apple orchards and the two deep wells 
investigated were unpolluted by nitrate, indicating that human activity had much lower effects on the soil in apple orchards than in vegetable greenhouses, and this may be attributed to the deep root systems of the apple trees efficiently intercepting the leached nitrate (Atkinson et al., 1978; Rowe et al., 1999; Gathumbi et al., 2003). Some studies have shown that woodland buffer strips reduce the discharge of groundwater nitrate into a nearby river by $73 \%$ (Takatert et al., 1999).

Nitrate- $\mathrm{N}$ concentrations in groundwater declined exponentially with well depth in the greenhouse areas. Numerous studies have shown this trend but have indicated a different stratified depth for dividing wells into the shallow and deep groups (Tesoriero and Voss, 1997; Hudak, 1999; Liu et al., 2005a). In our study, an arbitrary stratified depth of $15 \mathrm{~m}$ was a reasonable boundary because the nitrate- $\mathrm{N}$ concentration tended to decline sharply below $15 \mathrm{~m}$.

\section{Conclusions}

The total $\mathrm{N}$ inputs and surpluses in greenhouse vegetable production systems were significantly higher than in wheatmaize rotations and apple orchards. However, the extremely high fertilizer $\mathrm{N}$ inputs to vegetables accounted for just fewer than $40 \%$ of total $\mathrm{N}$ inputs. As a consequence, large amounts of nitrate accumulated in the vegetable soils and the shallow groundwater was heavily contaminated by nitrate- $\mathrm{N}$ in areas with intensive greenhouse vegetable production. Moreover, it must be pointed out that the annual fertilizer $\mathrm{N}$ inputs in the wheat-maize rotations and apple orchards were also much higher than the rates recommended by the local extension service and also led to relatively large amounts of nitrate accumulation in the soils. We conclude that improvements in farm management are required to lower the accumulation of nitrate in soils and groundwater while maintaining or improving agricultural productivity. This should be achieved by longterm studies to determine more accurately crop $\mathrm{N}$ requirements and by enhancing the local extension service to persuade farmers to minimize environmental degradation while maintaining high crop yields.

\section{Acknowledgments}

We acknowledge generous financial support from the National Natural Science Foundation of China (Grant nos 30270787 and 30390081) and a Key Project of the 15th National Plan (Grant no. 2004BA516A01).

\section{References}

Atkinson, D., Johnson, M.G., Mattan, D., Mercer, E.R., 1978. The effect of orchard soil management on the uptake of nitrogen by established apple trees. Journal of the Science of Food and Agriculture 30, 129-135.

Baker, D.B., Wallrabenstein, L.K., Richards, R.P., Creamer, N.L., 1989. Nitrate and Pesticides in Private Wells of Ohio: A State Atlas. The Water Quality Laboratory, Heidelberg College, Heidelberg, Germany.

Barry, D.A.J., Goorahoo, D., Goss, M.J., 1993. Estimation of nitrate concentrations in groundwater using a whole farm nitrogen budget. Journal of Environmental Quality 4, 767-775.
Bhogal, A., Rochford, A.D., Sylvester-Bradley, R., 2000. Net changes in soil and crop nitrogen in relation to the performance of winter wheat given wide-ranging annual nitrogen applications at Ropsley, UK. Journal of Agriculture Science, Cambridge 135, 139-149.

Chen, X.P., 2003. Optimization of the $\mathrm{N}$ fertilizer management of a winter wheat/summer maize rotation system in the Northern China Plain. PhD dissertation, University of Hohenheim, Stuttgart, Germany.

Editorial Committee of China Agricultural Yearbook, 1981-2003. China Agricultural Yearbook. China Agricultural Publishing House, Beijing (in Chinese).

Davies, D.B., Sylvester-Bradley, R., 1995. The contribution of fertilizer nitrogen to leachable nitrogen in the UK: a review. Journal of the Science of Food and Agriculture 68, 399-406.

Diez, J.A., Caballero, R., Roman, R., Tarquis, A., Cartagena, M.C., Vallejo, A., 2000. Integrated fertilizer and irrigation management to reduce nitrate leaching in Central Spain. Journal of Environmental Quality 29, $1539-1547$.

van Eerdt, M.M., Fong, P.K.N., 1998. The monitoring of nitrogen surpluses from agriculture. Environmental Pollution 102 (s1), 227-233.

Eichler, F., Schulz, D., 1998. The nitrogen reduction program in the Federal Republic of Germany. Environmental Pollution 102, 609-617.

Gathumbi, S.M., Cadisch, G., Buresh, R.J., Giller, K.E., 2003. Subsoil nitrogen capture in mixed legume stands as assessed by deep nitrogen-15 placement. Soil Science Society of America Journal 67, 573-582.

Granstedt, A., 2000. Increasing the efficiency of plant nutrient recycling within the agricultural system as a way of reducing the load to the environment experience from Sweden and Finland. Agriculture, Ecosystems \& Environment 80, 169-185.

Guimera, J., 1998. Anomalously high nitrate concentrations in ground water. Ground Water 36, 275-282.

Hofman, G., 1999. EU concerted action: nutrient management legislation in European countries. NUMALEC Report, Fair 6-CT98-4215. <www. uni-hohenheim.de/i3v/>.

Hudak, P.F., 1999. Chloride and nitrate distributions in the Hickory aquifer, Central Texas, USA. Environment International 25, 393-401.

Ju, X.T., Liu, X.J., Zhang, F.S., 2003. Accumulation and movement of $\mathrm{NO}_{3}^{-}-\mathrm{N}$ in soil profile in winter wheat/summer maize rotation system. Acta Pedologica Sinica 40, 538-546 (in Chinese with English abstract).

Ju, X.T., Liu, X.J., Zhang, F.S., Roelcke, M., 2004. Nitrogen fertilization, soil nitrate accumulation, and policy recommendations in several agricultural regions of China. Ambio 33, 300-305.

Keeney, D.R., Follett, R.F., 1991. Managing nitrogen for groundwater quality and farm profitability: overview and introduction. In: Follett, R.F., Keeney, D.R., Cruse, R.M. (Eds.), Managing Nitrogen for Groundwater Quality and Farm Profitability. ASA, CSSA, and SSSA, Madison, WI, pp. 1-7.

Kraft, G.J., Stites, W., 2003. Nitrate impacts on groundwater from an irrigatedvegetable systems in a humid north-central US sand plain. Agriculture, Ecosystems \& Environment 100, 63-74.

Laegreid, M., Bøckman, O.C., Kaarstad, O., 1999. Agriculture, Fertilizers and the Environment. CABI Publishing in association with Norsk Hydro ASA, Norsk Hydro ASA, Porsgrunn, Norway.

Liu, G.D., Wu, W.L., Zhang, J., 2005a. Regional differentiation of non-point source pollution of agriculture-derived nitrate nitrogen in groundwater in northern China. Agriculture, Ecosystems \& Environment 107, 211-220.

Liu, H.B., Zhang, Y.G., Li, Z.H., Zhang, W.L., Lin, B., 2005b. Nitrate contamination of deep groundwater in rural plain areas of Beijing. Acta Pedologica Sinica 42, 411-418 (in Chinese with English abstract).

Liu, H.B., Lei, B.K., Zhang, Y.G., Zhang, W.L., Lin, B., 2001. Investigation and evaluation on nitrate pollution ground water of Shunyi District. Plant Nutrition and Fertilizer Science 7, 385-390 (in Chinese with English abstract).

Liu, H.J., Ju, X.T., Tong, Y.A., Zhang, F.S., Lu, J.L., 2002. The status and problems of fertilization of main fruit trees in Shaanxi Province. Agricultural Research in Arid Areas 20, 38-44 (in Chinese with English abstract).

Liu, X.J., Ju, X.T., Zhang, F.S., Pan, J.R., Christie, P., 2003. Nitrogen dynamics and budgets in a winter wheat-maize cropping system in the North China Plain. Field Crops Research 83, 111-124. 
Ma, W.Q., 1999. Current status and evaluation of crop fertilization in Shandong Province. PhD thesis, China Agricultural University, Beijing, China (in Chinese with English summary).

Oenema, O., Kros, H., de Vries, W., 2003. Approaches and uncertainties in nutrient budgets: implications for nutrient management and environmental policies. European Journal of Agronomy 20, 3-16.

Parris, K., 1998. Agricultural nutrient balances as agri-environmental indicator: an OECD perspective. Environmental Pollution 102 (s1), 219-225.

Pionke, H.B., Sharma, M.L., Hirschberg, K.J., 1990. Impact of irrigated horticulture on nitrate concentrations in groundwater. Agriculture, Ecosystems \& Environment 32, 119-132.

Porter, L.K., Follett, R.F., Halvorson, A.D., 1996. Fertilizer nitrogen recovery in a no-till wheat-sorghum-fallow-wheat sequence. Agronomy Journal $88,750-757$.

Postle, J., 1999. Nitrate in groundwater - a continuing issue for Wisconsin citizens. Pollution Abatement Program Redesign. <www.dnr.state.wi.us/ org/water/dwg/gw/pubs $>$.

Prunty, L., Greenland, R., 1997. Nitrate leaching using two potato-corn $\mathrm{N}$-fertilizer plans on sandy soil. Agriculture, Ecosystems \& Environment $65,1-13$.

Puckett, L.J., Cowdery, T.K., Lorenz, D.L., Stoner, J.D., 1999. Estimation of nitrate contamination of an agro-ecosystem outwash aquifer using a nitrogen mass-balance budget. Journal of Environmental Quality 28, 20152025.

Ramos, C., Agut, A., Lidon, A.L., 2002. Nitrate leaching in important crops of the Valencian Community region (Spain). Environmental Pollution 118, 215-223.

Rass, D.J., Rithie, J.T., Peterson, W.R., Loudn, T.L., Martin, E.C., 1999. Nitrogen management impacts on yield and nitrate leaching in inbred maize systems. Journal of Environmental Quality 28, 1365-1371.

Raun, W.R., Johnson, G.V., 1995. Soil-plant buffering of inorganic nitrogen in continuous winter wheat. Agronomy Journal 87, 827-834.

Richter, J., Roelcke, M., 2000. The N-cycle as determined by intensive agriculture - examples from Central Europe and China. Nutrient Cycling in Agroecosystems 57, 33-46.

Rowe, E.C., Hairiah, K., Giller, K.E., van Noordwijk, M., Cadisch, G., 1999. Testing the safety-net role of hedgerow tree roots by ${ }^{15} \mathrm{~N}$ placement at different soil depths. Agroforestry Systems 43, 81-93.

Schleef, K.H., Kleihanss, W., 1994. Mineral Balance in Agriculture in the EU. Institute of Farm Economics, Federal Agricultural Research Centre, Braunschweig, Germany.

Schroder, J.J., van Asperen, P., van Dongen, G.J.M., Wijnands, F.G., 1996. Nutrient surpluses on integrated arable farms. European Journal of Agronomy $5,181-191$
Sonntag, B.H., Huang, J.K., Rozelle, S., Skerrit, J.H., 2005. China's agricultural and rural development in the early 21st century. ACIAR Monograph No. 116.

Stites, W., Kraft, G.J., 2000. Groundwater quality beneath irrigated vegetable fields in a north-central US sand plain. Journal of Environmental Quality 29, 1509-1517.

Stites, W., Kraft, G.J., 2001. Nitrate and chloride loading to groundwater from an irrigated north-central US sand plain vegetable fields. Journal of Environmental Quality 30, 1176-1184.

Sun, H., Shen, Y.Q., Shi, Y.L., Zhang, Q.X., Zhang, Q.L., 1994. Agricultural Natural Resources and Regional Development of China. Jiangsu Science and Technology Publishers, Nanjing, pp. 307-322 (in Chinese).

Takatert, N., Sanchez-Perez, J.M., Tremolieres, M., 1999. Spatial and temporal variations of nutrient concentration in the groundwater of a floodplain: effect of hydrology, vegetation and substrate. Hydrological Progresses 13, 1511-1526.

Tesoriero, A.J., Voss, F.D., 1997. Predicting the probability of elemental nitrate concentrations in the Puget Sound Basin: implications for aquifer susceptibility and vulnerability. Ground Water 35, 1029-1039.

Thorburn, P.J., Biggs, J.S., Weier, K.L., Keating, B.A., 2003. Nitrate in groundwater of intensive agricultural areas in coastal Northeastern Australia. Agriculture, Ecosystems \& Environment 94, 49-58.

Townsend, M.A., Sleezer, R.O., Macko, S.A., 1996. Effects of agricultural practices and vadose zone stratigraphy on nitrate concentration in ground water in Kansas, USA. Water Science Technology 33, 219-226.

Yadav, S.N., 1997. Formulation and estimation of nitrate-nitrogen leaching from corn cultivation. Journal of Environmental Quality 26, 808-814.

Zhang, W.L., Wu, S.X., Ji, H.J., Kolbe, 2004. The current situation and controlling manures of non-point source pollutions in China. Scientia Agricultura Sinica 37, 1008-1017 (in Chinese with English abstract).

Zhang, W.L., Tian, Z.X., Zhang, N., Li, X.Q., 1996. Nitrate pollution of groundwater in Northern China. Agriculture, Ecosystems \& Environment $59,223-231$.

Zhong, Q., 2004. Studies of nitrogen environmental endurance of winter wheat/summer maize rotation system in the North China Plain. Ms thesis, China Agricultural University, Beijing, China (in Chinese with English summary).

Zhu, J.H., Li, X.L., Christie, P., Li, J.L., 2005. Environmental implications of low nitrogen use efficiency in excessively fertilized hot pepper (Capsicum frutescens L.) cropping systems. Agriculture, Ecosystems \& Environment $111,70-80$.

Zhu, Z.X., Stewart, B.A., Fu, X.J., 1994. Double cropping wheat and corn in a sub-humid region of China. Field Crops Research 36, 175-183. 